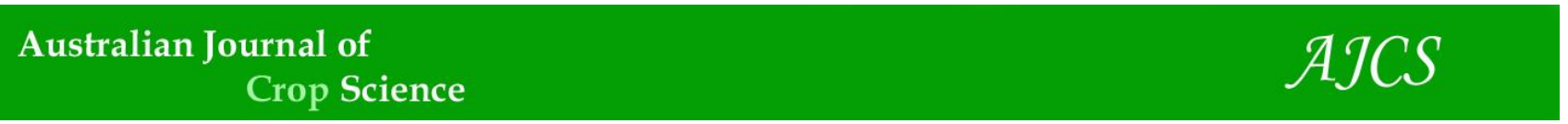

AJCS 15(02):284-289 (2021)

ISSN:1835-2707

doi: 10.21475/ajcs.21.15.02.p2997

\title{
Temporal and spatial progress of Cowpea aphid-borne mosaic virus (CABMV) in passion fruit (Passiflora edulis Sims)
}

\author{
Roger Yochiharu Kotsubo', Karina Silva dos Santos', Lucas Henrique Fantin², Vitória Carolina Antunes \\ Chaves', João Valdecir Casaroto Filho', Vinicius Ferrari Tissiano', Rúbia de Oliveira Molina'* \\ 'Institute of Rural Development of Paraná - IAPAR-EMATER (IDR-Paraná), Celso Garcia CID Highway, km 375, CEP \\ 86001-970, Londrina, PR, Brazil \\ ${ }^{2}$ Mand State University (UEL), Celso Garcia CID Highway, km 380, CEP 86057-970, Londrina, PR, Brazil
}

\section{*Corresponding author: rubiamolina@idr.pr.gov.br}

\begin{abstract}
Among the diseases that affect passion fruit, those causing fruit woodiness is considered the most important. Cowpea aphid-borne mosaic virus (CABMV) is an important vírus that is transmitted by several aphid species during the bite, making the use of insecticides infeasible to control these vectors. In order to understand the epidemiological behavior of the disease, this study aimed to study the temporal progress and spatial pattern of CABMV in the field. Healthy seedlings of passion fruit with 2.0 meters height were implanted in the field condition at the experimental station of the IDR-Paraná, Brazil. The evaluations were performed weekly observing the symptoms of blister, mosaic, chlorosis and crinkled leaves. For the analyses, the logistic, gompertz and monomolecular models were adjusted to CABMV incidence data in passion fruit. The spatial pattern of the disease was characterized by the dispersion index and Taylor's Power Law. The logistic model was the one that best described the progress in the incidence of the disease. The incidence progress rate of CABMV was $0.037,0.077$ and $0.060 \%$ day $^{-1}$. At the beginning of the epidemic, the pattern was random. The initial dispersion mechanism was occured through aphid vectors, como Aphis gossypii Glover, Aphis fabae Scopoli, Aphis solanella Theobald, Toxoptera citricida Kilkaldy, Uroleucon ambrosiae Thomas and Uroleucon sonchi L. infected with CABMV that starts its test bite randomly. The pattern of disease dispersion began to be added when the incidence of plants reached 10 and $7 \%$, in the 2015/16 and 2017/18 harvests, respectively. The random spatial pattern suggested that infected aphids enter several points of the orchard and infected plants become a source for secondary infections, characterizing aggregate pattern. Thus, the eradication of alternative hosts abroad can be adopted as management strategies of CABMV.
\end{abstract}

Keywords: aphids; epidemiology; fruit woodiness virus; non-linear models; spatial pattern. Abbreviations: IDR-Paraná_Institute of Rural Development of Paraná - IAPAR-EMATER.

Introduction

Passion fruit (Passiflora edulis Sims) is a species of great economic importance in Brazil, where its cultivation is one of the fastest growing in the fruit sector (Meletti, 2011). In 2019, more than 593.4 thousand tons of fruit were harvested from just over 41,800 hectares, showing a small decrease of $3.6 \%$ in relation to the previous year. Even with the drop in production, Brazil remains the largest producer of culture (IBGE, 2020).

Passion fruit has adapted well to small farms, being considered an important base for the economy of some municipalities in Paraná. Along with the increase in this cultivation, new problems arose, including poor conduction of orchards and plant nutrition, economic barriers and the occurrence of pests and diseases (Carvalho et al., 2015), while phytopathogens are the most limiting factors for production (Farias et al., 2013).

Among the diseases reported in passion fruit, what causes fruit woodiness (Cowpea aphid-borne mosaic virus - CABMV) is the most frequent and causes the most damage to the crop (Gioria et al., 2000; Farias et al., 2013). CABMV is currently considered the most important virus for the passion fruit culture (Martoneto et al., 2018; Stenzel et al.,
2019; Santos, 2020). The first report of this virus in Brazil, formerly described as PWV, was recorded in Feira de Santana, in the state of Bahia in the 1970s (Yamashiro and Chagas, 1979), resulting in declines in the production of passion fruit crops for the juice (Chagas et al., 1981; PioRibeiro and Mariano, 2005).

Recently, this disease has spread with greater intensity in Paraná, causing serious damage (Carvalho et al., 2015). First detected in mid-2014, it quickly reached the main production centers of yellow passion fruit in the state (Stenzel et al., 2019). CABMV epidemiological studies carried out by Narita et al. (2012), indicating that after the pathogen enters the area, the virus spreads quickly, being able to infect all plants in just four months.

This disease belongs to the Potyviridae family and genus Potyvirus. It presents initial symptoms at the ends of the growing branches, as mosaic leaves, showing yellowish ringshaped spots, mottling, roughness, curling and shriveling in the fruits. It also causes deformation, small size, hardened and thick pericarp and low pulp yield frequently occur in plant, growth impair, with shortening of the internodes of the branches and drastic reduction in production (Dos Anjos 
et al., 2001; Pio-Ribeiro and Mariano, 2005; Farias et al., 2013; Stenzel et al., 2019).

In nature, CABMV is transmitted during the test bites of several species of aphids (Yuki et al., 2006). Transmission of the non-persistent type carried out by these vectors makes the control of this disease difficult with use of insecticides due to the short period of permanence, acquisition and transmission of the virus. The product's action time on the aphid is insufficient to prevent the transmission process (Costa, 1998). The species described as vectors of CABMV in Brazil are: Myzus persicae Sulzer, Aphis gossypii Glover, Aphis Fabae Scopoli, Aphis Solanella Theobald, Toxoptera citricida Kilkaldy, Uroleucon ambrosiae Thomas, Uroleucon Sonchi Lineus and Myzus nicotianae (Costa et al., 1995; Inoue et al., 1995; Yuki et al., 2006).

Few measures are available to control this virus in areas, where it has already been settled, mentioning the use of healthy seedlings, elimination of alternative hosts of the pathogen, installation of the orchard with well-developed seedlings with approximately $2.0 \mathrm{~m}$ in height and the roguing of passion fruit infected by CABMV in the vegetative phase (Stenzel et al., 2019).

Knowing the occurrence, distribution and epidemiology of a pathogen and its relationship with a heterogeneous environment is necessary to determine the most appropriate way to manage the crop during the harvest and to adopt new control measures (Nutter, 1997). Thus, the present study aimed to characterize the temporal progress and the spatial pattern of the disease in the field.

\section{Results and discussion}

\section{Incidence of passion fruit with CABMV symptoms}

The logistic model showed a better fit to the incidence data, compared to the monomolecular and gompertz models (Table 1). In three years of evaluation, the maximum asymptote ranged from 0.99 to 1 . The rate of progress ( $r$ ) was lower in 2015/16 (0.037 per day) compared to 2016/17 and $2017 / 18$ (0.077 and 0.060 , respectively).

The occurrence of precipitation during the 2015/16 harvest was $2700 \mathrm{~mm}$, more than $1000 \mathrm{~mm}$ difference in relation to other crops. This may have been one of the factors responsible for the slower progression of CABMV in the 2015/16 crop, since precipitation is one of the abiotic factors that influence the increase or decrease in population of different species of aphids, and consequently, the spread of the virus (Robert, 1987). In the same year, the initial inoculum ( $y 0$ ) was $0.052 \%$ of infected plants and in other years less than $0.001 \%$ (Fig. 1).

By the adjusted models, in the 2016/17 and 2017/18 harvests, we estimated that half of the orchard was infected in 91 and 117 days, respectively. In 2015/16 crop, the model estimated this as 80 days. The results indicate that the initial inoculum (Number of infected plants) showed greater progress in incidence in the orchard.

\section{Spatial distribution of the disease caused by CABMV}

The spatial model of incidence of symptomatic plants can be seen in Fig 2. The dispersion pattern of CABMV "random" (D = 1) was observed in the 2016/17 trial (Fig. 2). In 2015/16 and 2017/18, the dispersion of CABMV became "aggregated" when the incidence reached $10 \%$ and $7 \%$, respectively (Table 2 ). The disease incidence rate was slower in the $2015 / 16$ crop, compared to the $2016 / 17$ and $2017 / 18$ crops, where in the first crop $74 \%$ of symptomatic plants were found after 102 DAT. In the 2016/17 crop, the incidence jumped up from $13 \%$ to $71 \%$ in just 18 DAT and in the $2017 / 18$ crop, the progression rate increased from $22 \%$ to $71 \%$ in 21 DAT (Table 2).

Coutts et al. (2004), evaluated the incidence of Tomato spotted wilt virus transmitted by thrips (Frankliniella schultzei) in lettuce (Lactuce sativa) and observed a slow rate of disease progression, indicating secondary spread. Rodrigues et al. (2019) reported more abrupt progression in Begomovirus transmitted to passion fruit by whitefly (Bemisia tabaci) similar to that found in the present study. These abrupt changes in the incidence of the disease may be related to the increase in the population of the vectors, influenced by favorable environmental conditions, alternative hosts in adjacent areas and virus/vector ratio. Among the forms of virus transmission by aphids, the nonpersistent is the one that has greatest potential for loss in different cultures (Costa, 1998). In this type of transmission, aphids have no specificity for acquiring the virus and can be acquired without the need to colonize the plant, during the test stings (Zerbini Júnior; Maciel-Zambolim, 1999). CABMV infest a wide range of host plants (Bock, 1973; Edwardson and Christie, 1986; Chang and Kuo, 1988). This has been reported in unnatural hosts and among weeds (Konate; Neya, 1996). This virus infects many species of the Fabaceae Family (Leguminosae) and most strains can infect members of Amaranthaceae, Chenopodiaceae, Cucurbitaceae, Labiatae and Solanaceae (Lovisolo; Conti, 1966; Bos, 1970; Bock, 1973).

The model that best described the evolution of the incidence of the disease was the logistical one with the lowest rate of evolution of the incidence of CABMV verified in the 2015/16 trial with $0.037 \% \mathrm{day}^{-1}$. Possibly, the high precipitation $(\mathrm{mm})$ in this period may have influenced the population dynamics of aphids in the area, reducing the transmission of the virus. Correlation studies between aphids and environmental factors carried out by Santos (2020) in the city of Londrina Brazil, pointed out that hotter and drier periods, with temperatures around $25 \circ \mathrm{C}$ favors the increase of the population of the main vector species (Aphis spp., Toxoptera citricidus and Uroleucon ambrosiae). Lamborot and Guerrero (1979) found that drier periods favor the population growth of aphids (1979). According to Carvalho et al. (2002), aphids are located in vulnerable parts of the plant, where as in rainy periods they can easily reach them to compromise their population.

The distribution pattern of CABMV started at random and started to be aggregated (incidence> 7\%). The same was observed for the "stem bleeding disease of coconuts", where Carvalho et al. (2013) and Rodrigues et al. (2019) mention that diseases caused by Begomovirus in passion fruit also follow an aggregating pattern.

Upon reaching the areas, the vectors infected by CABMV spread to perform the test stings, which initially show a random spatial pattern of symptomatic plants. As these infected vectors move around the area, the aggregation of symptomatic plants increases. The same distribution behavior was observed by Jesus Junior and Bassanezi (2004) analyzing the sudden death of citrus (MSC). This indicates a similar action in diseases caused by some infectious agent, 
Table 1. Parameters and errors calculated through monomolecular, logistic and Gompertz nonlinear regression models at CABMV incidence data in the $2015 / 16$ to $2017 / 18$ crop seasons.

\begin{tabular}{|c|c|c|c|c|c|c|c|}
\hline Crop & Model & $\begin{array}{l}\text { Parameter } \\
\mathrm{R}^{2}\end{array}$ & $y_{\max }$ & $\mathrm{Y}_{\max } \mathrm{SE}$ & $Y_{0}$ & $Y_{0} S E$ & $r$ \\
\hline \multirow{4}{*}{$2015 / 16$} & Monomolecular & Not adjusted & & & & & \\
\hline & Logistic & 0.9920 & 1.078 & 0.035 & 0.052 & 0.009 & 0.037 \\
\hline & Gompertz & 0.9889 & 1.238 & 0.087 & 0.027 & 0.011 & 0.020 \\
\hline & Monomolecular & Not adjusted & & & & & \\
\hline \multirow[t]{2}{*}{$2016 / 17$} & Logistic & 0.9999 & 0.990 & 0.004 & $<0.001$ & $<0.001$ & 0.077 \\
\hline & Gompertz & Not adjusted & & & & & \\
\hline \multirow{3}{*}{$2017 / 18$} & Monomolecular & Not adjusted & & & & & \\
\hline & Logistic & 0.9988 & 0.995 & 0.014 & $<0.001$ & $<0.001$ & 0.060 \\
\hline & Gompertz & Not adjusted & & & & & \\
\hline
\end{tabular}

$y$ is the incidence of symptomatic plants, $t$ is the time in days, ymax to asymptote, y0 is the initial inoculum, $r$ is the progress of the disease, $R^{2}$ coefficient of determination and SE is the standard error of the mean.
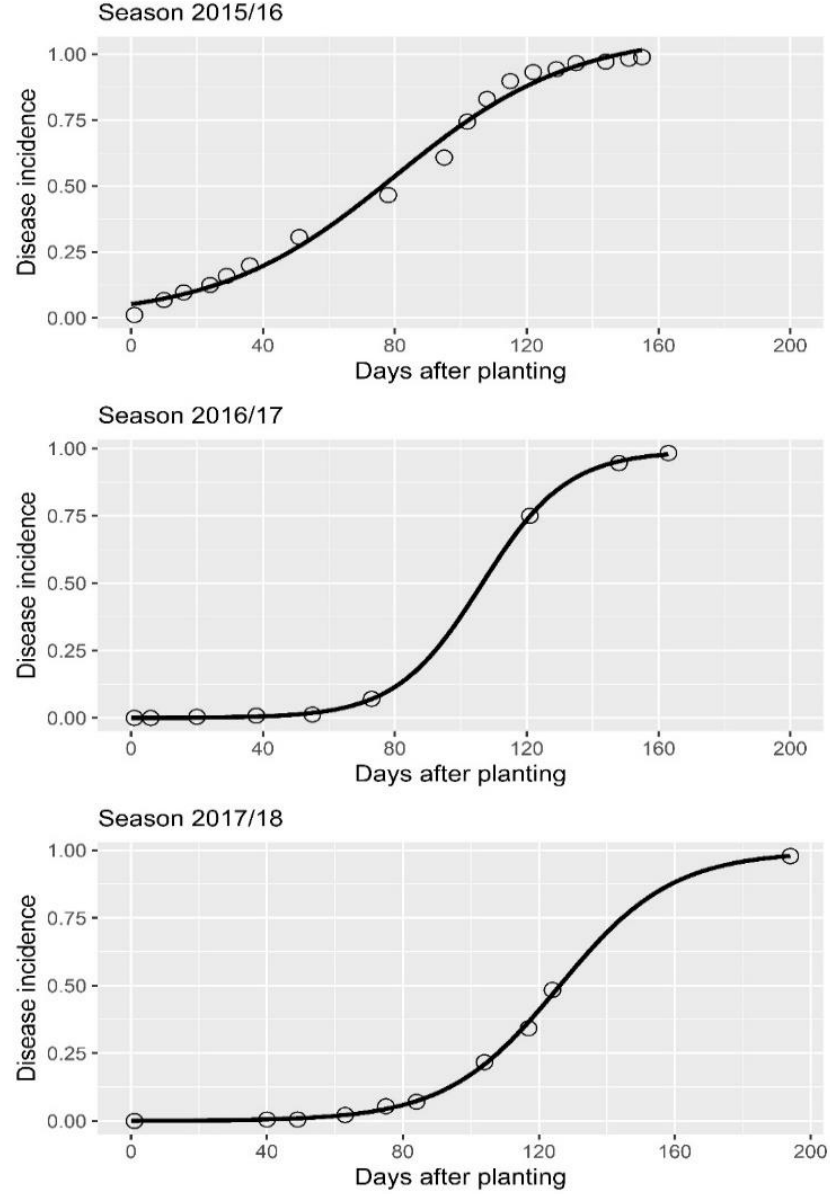

Fig 1. Incidence of passion fruit presenting symptoms of Cowpea aphid-borne mosaic virus (CABMV) during the 2015/16, 2016/17 and 2017/18 trials in the state of Paraná, Brazil. Solid lines indicate the logistic model adjusted to the incidence of the disease.

Table 2. Incidence and distribution pattern of Cowpea aphid-borne mosaic virus (CABMV) in passion fruit in trials conducted from 2015/16 to 2017/18 at the IDR Paraná, Londrina-PR.

\begin{tabular}{|c|c|c|c|c|c|c|c|c|c|c|c|}
\hline \multicolumn{4}{|c|}{ Season $15 / 16$} & \multicolumn{4}{|c|}{ Season 16/17 } & \multicolumn{4}{|c|}{ Season $17 / 18$} \\
\hline DAT & I (\%) & $\mathrm{D}$ & $\mathrm{p}$-value & DAT & I (\%) & $\mathrm{D}$ & $p$-value & DAT & $\mathrm{I}(\%)$ & $\mathrm{D}$ & $\mathrm{p}$-value \\
\hline 10 & 0.07 & 0.982 & 0.505 & 6 & 0 & - & - & 40 & 0.005 & 1.006 & 0.4649 \\
\hline 24 & 0.1 & $1.754^{*}$ & 0.002 & 20 & 0.004 & 1.004 & 0.467 & 49 & 0.005 & 1.006 & 0.4649 \\
\hline 36 & 0.2 & $1.94 *$ & $<0.001$ & 38 & 0.008 & 0.991 & 0.494 & 63 & 0.022 & 0.994 & 0.4958 \\
\hline 51 & 0.31 & $2.234^{*}$ & $<0.001$ & 55 & 0.013 & 0.978 & 0.522 & 75 & 0.054 & 0.957 & 0.5937 \\
\hline 78 & 0.47 & $2.037^{*}$ & $<0.001$ & 73 & $0.071 *$ & 1.428 & 0.018 & 84 & 0.071 & $1.299 *$ & 0.0318 \\
\hline 95 & 0.61 & $1.824^{*}$ & $<0.001$ & 121 & 0.75 & 1.04 & 0.392 & 104 & 0.217 & $1.39 *$ & 0.0095 \\
\hline 102 & 0.74 & $1.741 *$ & $<0.001$ & 148 & 0.946 & 0.842 & 0.801 & 117 & 0.342 & $1.418^{*}$ & 0.0063 \\
\hline 115 & 0.9 & 1.18 & 0.195 & 163 & 0.983 & 0.965 & 0.552 & 124 & 0.484 & $1.31^{*}$ & 0.0277 \\
\hline 122 & 0.93 & 0.982 & 0.505 & & & & & 197 & 0.978 & 0.988 & 0.5116 \\
\hline 129 & 0.94 & 0.838 & 0.765 & & & & & & & & \\
\hline 135 & 0.97 & 0.915 & 0.631 & & & & & & & & \\
\hline 144 & 0.97 & 0.933 & 0.596 & & & & & & & & \\
\hline 155 & 0.99 & 0.988 & 0.494 & & & & & & & & \\
\hline
\end{tabular}

*Significances $\left({ }^{*}\right)$ were calculated by the chi-square distribution; significant values indicate aggregation pattern. 


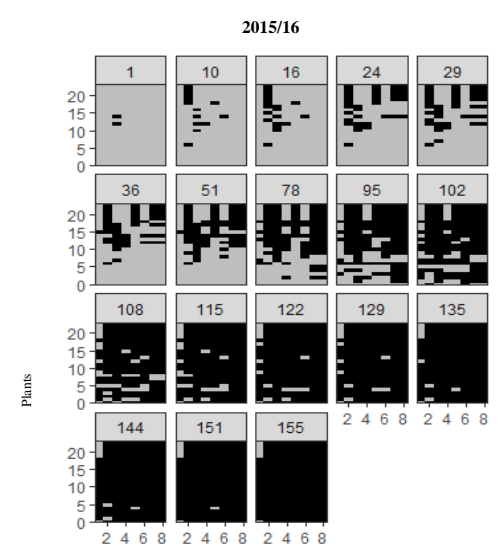

Plants

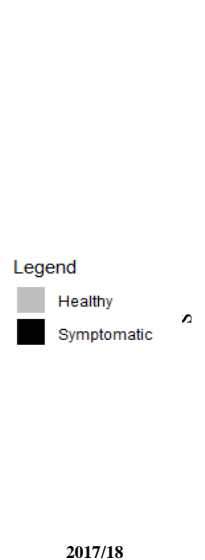

017/18

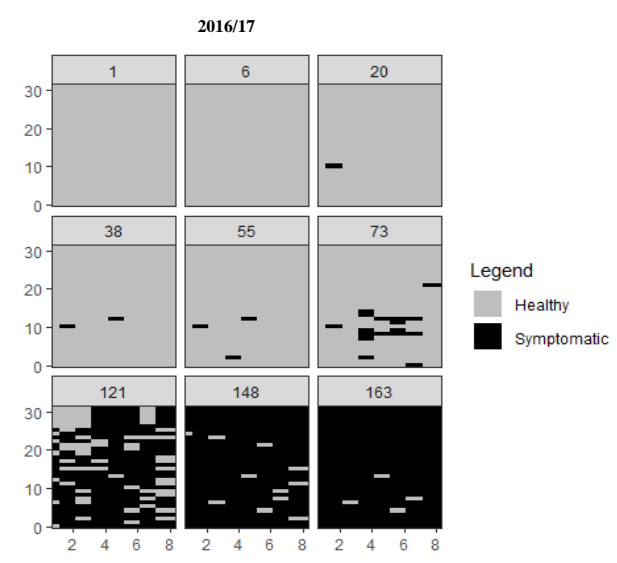

Plants

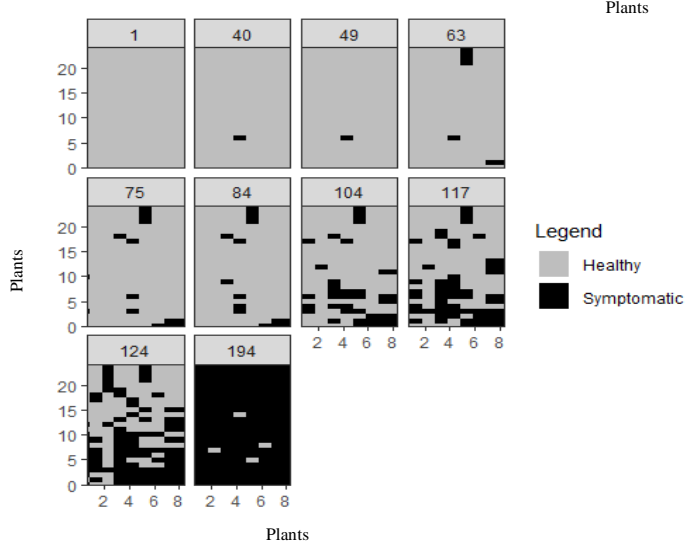

Fig 2. Spatial distribution map of fruit hardening disease caused by Cowpea aphid-borne mosaic virus (CABMV) evaluated for a period of up to 194 days, in an orchard at the IDR Paraná, Londrina-PR.

transmitted by insect vectors. In the present study, the dispersion pattern of CABMV varied according to the year of driving. In 2016/17, the distribution of the disease followed a random pattern. In the other harvests, the pattern was aggregating. Factors such as the presence of inoculum in adjacent areas, edaphoclimatic conditions and population fluctuation of aphids vectors can influence the dispersion pattern. Macedo et al. (2017) showed differences in the distribution pattern of diseases caused by Begomovirus in tomato plots (Solanum lycopersicum) located in the center (higher frequency of aggregates) and portions at the edges. The authors suggest that the distribution of plants with symptoms may indicate three mechanisms of dissemination: "one random (primary) and two aggregates, a real secondary spread and a false secondary spread". Vecchia et al. (2007) suggested aggregating pattern at the edges of the area attributed the migration of vectors from external/adjacent areas that present the presence of infected plants. The pattern varies according to the virus. For example, plants infected with the Tomato chlorosis virus (ToCV) showed a higher frequency of the aggregate pattern than plants infected with the Tomato severe rugose virus (ToSRV) (Macedo et al., 2019).

\section{Materials and methods}

\section{Production and installation of healthy seedlings in the field}

The experiments were conducted at the experimental station of the Institute of Rural Development of Paraná -
IAPAR-EMATER (IDR-Paraná), located in Londrina, Brazil, altitude of $565 \mathrm{~m}$, latitude $23^{\circ} 21^{\prime} 36.6^{\prime} \mathrm{S}$; longitude $51^{\circ} 10^{\prime} 07$. 8 "W.

The passion fruit seedlings, cultivar "Morning light", used to evaluate the experiments in a greenhouse. The transplantation of healthy seedlings to the field was performed after reaching approximately $2.0 \mathrm{~m}$ of height. For the implantation of the seedlings, the vertical backrest system was used with the conduction being carried out by 1 wire, arranged $1.90 \mathrm{~m}$ from the ground. The experimental units were installed with spacing of $3.0 \mathrm{~m}$ between rows and $2.0 \mathrm{~m}$ between plants.

\section{Experimental design}

Experiment was perfomanced between 2015 and 2018. In 2015-2016 harvest the experiment was installed with 22 plants in each row, totaling 176 plants, the harvest from 2016 to 2017 with 30 plants in each row totaling 240 plants and in the 2017 to 2018 harvest with 20 plants in each row, totaling 160 plants.

\section{Assessment of symptoms}

After one month, each plant was visually inspected at 7-day intervals for a period of up to 194 days to detect symptoms of blister, mosaic, chlorosis and crinkled leaves, characteristic of Cowpea aphid-borne mosaic virus (CABMV). 


\section{Statistical analysis}

The incidence of symptomatic plants $(\mathrm{y})$ was determined by: $y-D / T$

In which, D represents the total number of symptomatic plants and $T$ is the total number of plants in the area. The disease progress curves were plotted using the incidence of symptomatic passion fruit plants over time. Disease progress was analyzed and the disease progress curve was adjusted by monomolecular models $[y(t)=y \max -(y \max -y 0) *$ and $-r t]$, logistic $[y(t)=y \max /(1+((y \max -y 0) / y 0) *$ $e-r t))]$ and Gompertz $[y(t)=y \max *(e-(-\log ((y \max -$ $y 0) / y 0) * e-r t)$ ]

To choose the model that is most appropriate, we used the coefficient of determination $\left(R^{2}\right.$, distance between the observed and predicted values), the average minimum square (LMS) and the absence of trends in the residual graph (Campbell and Madden, 1990; Carvalho et al., 2013).

Statistical and graphical analyses were performed with the aid of the R program (R Core Team, 2019), and packages "nlstools" (Baty et al., 2015) and "ggplot2" (Wickham, 2016) The spatial pattern of CABMV was given through the construction of cumulative maps of symptomatic (infected) plants and their respective position in the orchard. In each evaluation, incidence data were converted into matrix $(x, y$, $z$ ), where $x=$ line, $y=$ plant on line and $z=$ plant state (Asymptomatic $=0$ and symptomatic $=1$ ).

Fischer dispersion index (D) and modified Taylor's law were used to characterize the spatial pattern. The "quadrats" with $2 \times 2$ size (plants in the line $x$ planting line) were used to obtain the dispersion index. The dispersion index (D) is clculated by the ratio between the observed variance Vobs $=\sum(X i-n p)^{2} / n^{2}(N-1)$ and the binomial Vbin $=$ $p(1-p) / n$ variance, in which: $\mathrm{Xi}$ represents the total number of symptomatic plants per "quadrat", $p$ is the incidence, $\mathrm{n}$ is the number of plants per "quadrat", and $\mathrm{N}$ represents the total number of "quadrats" each area. Three patterns were tested: random, grouped and uniform. The chi-squared under the hypothesis of non-aggregation was used (Madden and Hughes, 1995).

\section{Conclusions}

The evolution of CABMV follows a logistic model with an orchard incidence of $50 \%$ between 80 and 117 days after the onset of infection. The random spatial pattern initially suggests that infected aphids enter various points in the orchard and the infected plants become a source of secondary infections, since the virus / vector relationship is nonpersistent, characterizing the aggregate pattern.

The results reinforce the importance of monitoring symptoms in the orchard and managing the host in adjacent areas.

\section{Acknowledgments}

Thanks to the Coordenação de Aperfeiçoamento de Pessoal de Ensino Superior - CAPES and to Institute of Rural Development of Paraná - IAPAR-EMATER (IDR - Paraná), for providing the opportunity for the research. We would like to appreciate the researchers, professors, technicians, fellows and trainees of the IDR - Paraná Virology Laboratory for the support in the development of this work.

\section{References}

Baty F, Ritz C, Charles S, Brutsche M, Flandrois JP, Delignette-Muller ML (2015) A Toolbox for Nonlinear Regression: R - The Package nlstools. J Stat Softw. 66(5):121.

Bock KR (1973) East African strains of Cowpea aphid-borne mosaic virus. Ann Appl Biol. 74:75-83.

Bos $L$ (1970) The identification of three new virus isolates from Wisteria and Pisum in the Netherlands, and the problem of variation within the Potato virus $Y$ group. $J$ Plant Pathol. 76:8-46.

Campbell CL, Madden LV (1990) Introduction to plant disease epidemiology. John Wiley \& Sons, New York, p. 532.

Carvalho LM, Bueno VHP, Martinez RP (2002) Alate aphids survey on vegetable crops in Lavras (MG). Ciênc Agrotec. 26:523-532.

Carvalho RRDCE, Souza PE, Warwick DRN, Pozza EA, Carvalho Filho JLS (2013) Spatial and temporal analysis of stem bleeding disease in coconut palm in the state of sergipe, Brazil. An Acad Bras Ciênc. 85(4):1567-1576.

Carvalho SLC, Stenzel NMC, Auler PAM (2015) Yellow passion fruit: Technical recommendations for cultivation in Paraná. IAPAR, Londrina, p. 54.

Chagas CM, Kitajima EW, Lin MT (1981) Severe yellow passion fruit disease (Passiflora edulis $\mathrm{f}$. Flavicarpa) in the State of Bahia, caused by an isolate of the Passion fruit woodiness virus. Fitopatol Bras. 6(2):259-268.

Chang CA, Kuo YJ (1988) Cowpea aphid-borne mosaic virus and its effect on the yield and quality of asparagus bean. $J$ Agri Res. 32:270-278.

Costa AF, Brás ASK, Carvalho MG (1995) Transmission of the passion fruit hardening virus (VEFM) by aphids (Hemiptera-Aphididae). Fitopatol Bras. 20:376

Costa CL (1998) Plant virus vectors: Insects. Rev An Patol Plant. 6:103-171.

Coutts BA, Thomas-Carroll ML, Jones RAC (2004) Patterns of spread of Tomato spotted wilt virus in field crops of lettuce and pepper: spatial dynamics and validation of control measures. Ann Appl Biol. 145:231-245.

Dos Anjos JR, Junqueira NTV, Charchar MJA (2001) Incidence and distribution of the passion fruit hardening virus in the Cerrado of Central Brazil. EMBRAPA Cerrados, Planaltina, Brazil. 1 -

Edwardson R, Christie RG (1986) Viruses Infecting Forage Legumes, vol 2. University of Florida, Gainsville, Agriculture Experimental Station, p. 742.

Farias DH, Fróes TL, Jesus ON, Barbosa CJ, Bruckner $\mathrm{CH}$, Abreu EFM (2013) Molecular detection of Cowpea aphidborne mosaic virus (CABMV) in Passiflora edulis. Paper presented at the XVIII Met - National Meeting on Methodologies and Management of Laboratories and $\mathrm{V}$ Symposium on Analytical Procedures and Traceability of Results in Agriculture, Salvador, from October 28 to November 1, 2013.

Gioria R, Bosquê GG, Rezende JAM, Amorim L, Kitajima EW (2000) Incidence of passion fruit viruses in Alta Paulista $\mathrm{SP}$, and damage caused by the "Passion fruit woodiness virus". Fitopatol Bras. 25:182-189.

IBGE - Instituto Brasileiro de Geografia e Estatística (2020) Results of municipal agricultural production. IBGE, Rio de Janeiro, Brazil. 
Inoue AK, Mello RN, Nagata T, Kitajima EW (1995) Characterization of Passion fruit woodiness virus isolates from Brasília and surrounding region, Brazil. Fitopatol Bras. 20:479-485.

Jesus Junior WC, Bassanezi RB (2004) Dynamics and structure analysis of citrus sudden death foci. Fitopatol Bras. 29:399-405.

Konate G, Neya BJ (1996) Rapid detection of Cowpea aphidborne mosaic virus in cowpea seed. Ann App Biol. 129(2):261-266.

Lamborot CHL, Guerrero SMA (1979) Dinâmica populacional de los afídeos de cereales y sus inemigos naturales in la Provincia de Santiago durante lãs temporadas 1976 y 1977. Investig Agric. 5:23-32.

Lovisolo O, Conti M (1966) Identification of an aphidtransmitted Cowpea mosaic virus. J Plant Pathol. 72:265269.

Macedo MA, Costa TM, Barbosa JC, Pereira JL, MichereffFilho M, Gilbertson RL, Inoue-Nagata AK, Bergamin Filho A (2017) Temporal and spatial dynamics of begomovirus disease in tomatoes in central Brazil. Plant Pathol. 66(4):529-538.

Macedo MA, Inoue-Nagata AK, Silva TNZ, Freitas DMS, Rezende JAM, Barbosa JC, Michereff-Filho M, Nascimento AR, Lourenção AL, Bergamin Filho A (2019) Temporal and spatial progress of the diseases caused by the Crinivirus Tomato chlorosis virus and the Begomovirus Tomato severe rugose virus in tomatoes in Brazil. Plant Pathol. 68(1):72-84.

Madden LV, Hughes G (1995) Plant Disease Incidence: Distributions, Heterogeneity, and Temporal Analysis. Annu Rev Phytopathol. 33:529-564.

Martoneto LS, Chaves VCA, Kotsubo RY, Carmo CM, Molina RO. Evaluation of the Cowpea aphid-borne mosaic virus (CABMV) in an orchard of yellow passion fruit (Passiflora edulis). Article presented at the Symposium on Updating in Agronomic Sciences (SACA), State University of Londrina, Paraná, Brazil, 2018.

Meletti LMM (2011) Advances in passion fruit culture in Brazil. Rev Bras Frutic. E: 83-91.

Narita N, Yuki VA, Narita HH, Hirata ACS (2012) Yellow passion fruit: technology aimed at living with the fruit hardening virus. Pesquisa \& Tecnologia, São Paulo, Brazil.
Nutter FW (1997) Quantifying the temporal dynamics of plant virus epidemics: a review. Crop Protection. 16:603618

Pio-Ribeiro G, Mariano RLR (2005) Diseases of Passion Fruit (Passiflora spp.). In: Kimati H, Amorim L, Rezende JAM, Bergamin Filho A, Camargo LEA (eds.) Phytopathology manual: diseases of cultivated plants. Agronomic Ceres, São Paulo, Brazil. 55 -

R Core Team (2019) R: A language and environment for statistical computing. R Foundation for Statistical Computing, Vienna, Austria.

Robert Y (1987) Aphids and their environment. In: Minks AK, Hawerwing P (eds) Aphids, their Biology: Natural Enemies and Control, vol 2. Elsevier Science Publisher, Amsterdam. 8 -

Rodrigues GB, Rocha Sobrinho GG, Mituti T, Bergamin Filho A, Amorim L, Rezende JAM, De Novaes QS (2019) Etiology, occurrence and epidemiology of a Begomovirus disease in passionflower in the southwest of Bahia. Sci Agric. 76(4):337-343.

Santos KS (2020) Survey of fruit hardening virus (Cowpea aphid-borne mosaic virus - CABMV) and aphids in passion fruit in Paraná. Paraná Agronomic Institute, Londrina, Brasil, p. 90.

Stenzel NMC, Auler PAM, Molina RO, Soares Júnior D (2019) Cultivation of yellow passion fruit: in areas where the fruit hardening virus (CABMV) occurs. IAPAR, Londrina, p. 29.

Vecchia MGSD, Rosa DD, Bergamin Filho A, Amorim L, Rezende JAM, Ribeiro A (2007) Spatio-temporal pattern of a begomovirus disease caused by Tomato yellow vein streak virus in tomato in Campinas region, São Paulo. Summa Phytopathol. 33(4):388-396.

Wickham H (2016) Ggplot2: Elegant Graphics for Data Analysis. Springer-Verlag, New York, p. 216.

Yamashiro T, Chagas CM. Occurrence of a serious viral disease in yellow passion fruit in the State of Bahia. Summary presented at the 5th Brazilian Fruit Congress, Brazilian Fruit Society, Pelotas, Brazil, 1979.

Yuki VA, Mizote FA, Narita N, Hojo H, Delfino MA, Oliveira DA (2006) Epidemiology of the passion fruit hardening virus in the producing region of Alta Paulista, SP. Summa Phytopathol. 32:19.

Zerbini Júnior FM, Maciel Zambolim E (1999) The Family Potyviridae part I. Rev Anu Patol Plant. 7:1-50. 